\title{
Chapter 31 \\ Potential Futures of Biological Invasions in South Africa
}

\author{
John R. Wilson (D), John Measey $\mathbb{D}$, David M. Richardson $\mathbb{D}$, Brian W. van \\ Wilgen $\mathbb{D}$, and Tsungai A. Zengeya
}

\begin{abstract}
Biological invasions are having a moderately negative impact on human livelihoods and the environment in South Africa, but the situation is worsening. Predicting future trends is fraught with many assumptions, so this chapter takes an outcome-orientated approach. We start by envisaging four scenarios for how biological invasions might look like 200-2000 years from now: (1) "Collapse of Civilisation, but no return to Eden", there is no advanced human civilisation left on Earth and current biological invasions play out in full; (2) "New Pangea", a combination of the unregulated and rapid movement of species around the world and other global change drivers leads to the biotic homogenisation of areas that were previously distinct biogeographic regions such that the concept of biological invasions no longer has meaning; (3) "Preserve or Use", while parts of the Earth continue to be utilised, some areas are actively managed and native biodiversity and biogeographic distributions are maintained; and (4) "Conservation Earth", a highly advanced civilisation restores the Earth to a state prior to the human-mediated movement of organisms (i.e. biological invasions are reversed).

Based on various horizon-scanning exercises and our own deliberations, we discuss how technological, socio-political, trade, global change, and ecological-
\end{abstract}

\footnotetext{
J. R. Wilson $(\bowtie)$

South African National Biodiversity Institute, Kirstenbosch Research Centre, Cape Town, South Africa

Centre for Invasion Biology, Department of Botany and Zoology, Stellenbosch University, Stellenbosch, South Africa

e-mail: john.wilson2@gmail.com

J. Measey · D. M. Richardson · B. W. van Wilgen

Centre for Invasion Biology, Department of Botany and Zoology, Stellenbosch University, Stellenbosch, South Africa
}

T. A. Zengeya

South African National Biodiversity Institute, Kirstenbosch Research Centre, Cape Town, South Africa

Centre for Invasion Biology, Department of Zoology and Entomology, University of Pretoria, Pretoria, South Africa

B. W. van Wilgen et al. (eds.), Biological Invasions in South Africa, Invading

Nature - Springer Series in Invasion Ecology 14,

https://doi.org/10.1007/978-3-030-32394-3_31 
evolutionary processes in South Africa might affect biological invasions by 2070 (i.e. when people born today will be the key decision-makers). Finally, we explore how planning, regulation, funding, public support, and research might affect invasions by 2025 (i.e. over the next planning/management/political cycle). There are many things we can neither predict nor influence, but, in part based on the insights from this book, we highlight some actions that could enable the next generation to decide what they want their future to be. A greater focus on appropriate and innovative training opportunities would increase the efficacy and responsiveness of the management of biological invasions. A shift in regulatory approach from "identify and direct" to a variety of flexible, inclusive, and sophisticated approaches underpinned by evidence might provide more societally acceptable means of addressing the multitude of competing interests. Greater co-operation on biosecurity and implementation with neighbouring countries would assist prevention measures. Finally, monitoring and research aimed at documenting, tracking, and predicting invasions and their impacts would assist with efforts to identify priorities and help us to understand the consequence of different management and policy decisions. While this was a sobering exercise, it was also empowering. If South Africans can agree on a long-term trajectory for how they want to deal with biological invasions, the potential consequences of decision-making over the short-term will become much clearer.

\subsection{Introduction}

This book on biological invasions in South Africa has focussed on the current state of invasions in South Africa and the processes that have led us to this point. It has highlighted the fascinating interplay between socio-economic factors and biological processes that have determined which alien species have been introduced, where they have spread to, what impacts have occurred, and how South African society has responded. This is largely because the book set out to be encyclopaedic (van Wilgen et al. 2020a, Chap. 1). However, biological invasions are fundamentally dynamic and are an important component of global change (van Wilgen et al. 2020b, Chap. 29). It would therefore be remiss not to conclude with an evaluation of what the future might bring. This chapter examines possible scenarios for biological invasions globally and in South Africa, and aims to show how different events and decisions could set us on radically different trajectories.

There has been an increasing wave of interest in conducting horizon-scanning, both for conservation generally and for invasion science specifically, with the aim of anticipating and preparing for problems (Ricciardi et al. 2017; Sutherland and Woodroof 2009). However, such exercises typically only consider what could happen over the next few planning cycles. This chapter takes a different approach. Although we rely heavily on existing projections, we focus first on the long-term (i.e. on what the "end-points" might be), and work back through time. Our approach was inspired by a recent exercise that considered potential futures for human 
civilisation and identified four basic trajectories: civilisation could conquer space; technological transformations could be such that what we now recognise as 'human' would no longer be relevant; civilisation could continue to develop, but with no transformative changes (status quo); or there could be a catastrophic end (Baum et al. 2019). These trajectories form the basis for evaluating the consequences of actions taken now. Thinking in this way balances short-termism that permeates most planning and political cycles and pitches thinking back into 'Long Now' time scales consistent with the functioning of ecosystems (Brand 2008). On this basis, and noting that the focus is on biological invasions rather than other global change drivers, we consider invasions over three time-periods:

- The long-term: the transfer of species across biogeographical barriers by humans in South Africa started slowly probably around 2000 years before present and has accelerated particularly over the last 200 years (Deacon 1986; Faulkner et al. 2020, Chap. 12). What will the situation look like in South Africa 200-2000 years from now? We assume that there will have been no significant shifts in tectonic plates (although there might be significant tectonic activity, important shifts in ocean currents, and sea-level changes), and assume that substantially new and diverse phylogenetic lineages will not yet have evolved.

- 2070: the need for inter-generational thinking is a principle embedded within conservation science; the choice of a 50-year time horizon is meant to reflect this. Specifically, what will South Africa look like when children born today become the decision makers? (although the age profile of decision-makers might and maybe should shift).

- 2025: current decisions are, of course, still made in the context of policy and management planning horizons, usually covering no more than the next 5 years (e.g. elections or government funding cycles).

For the 2070 and 2025 time periods we consider how different events and drivers are likely to put us on a trajectory to one of the long-term scenarios.

\subsection{The Long-Term: What Will Invasions Look Like 200-2000 Years from Now?}

Below we sketch out four long-term scenarios (Table 31.1). The inspiration for these came largely from the scenarios of Baum et al. (2019) and post-lunch discussions at the wine farm Lovane (close to Stellenbosch). However, they undoubtedly also arose from nascent ideas buried deep in our memories of concepts more eloquently expressed by other authors.

First, we consider "Collapse of civilisation, but no return to Eden". In this scenario, a disastrous event (or series of events) leads to the extinction of Homo sapiens, or, of more specific relevance to biological invasions, leads to a situation 


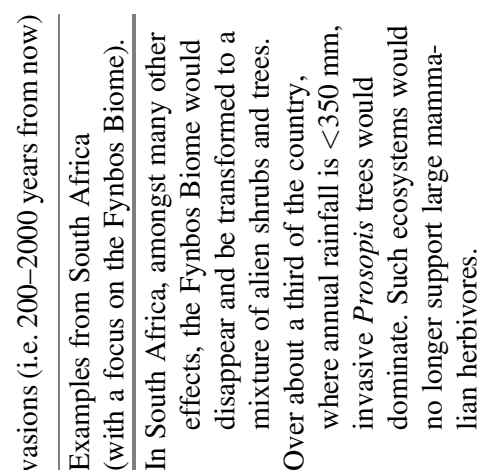

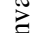

ฮ

$\frac{0}{00}$

$\frac{0}{3}$

(5)

.

政

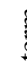

든

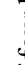

4

:

。

๖ัต

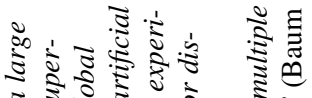

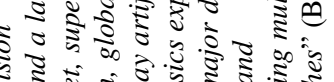

ฐิษ

$\frac{0}{2}$

:

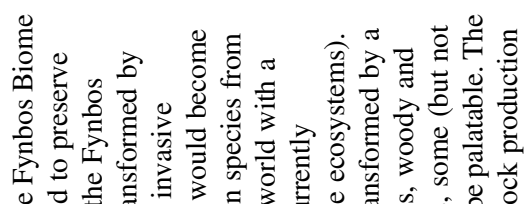

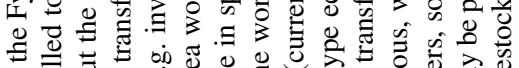

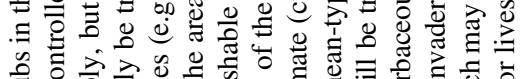

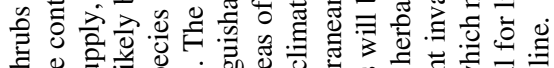

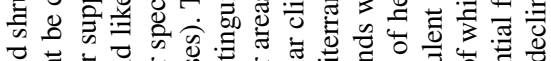

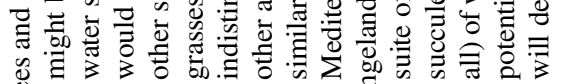
递

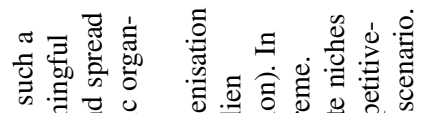

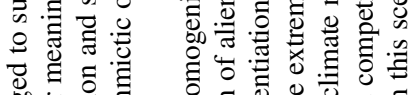

吅

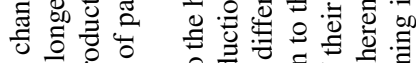

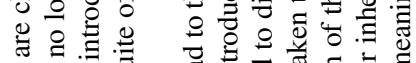

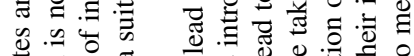

过

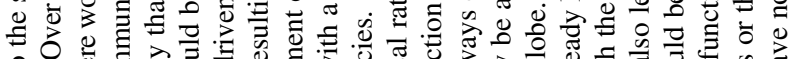

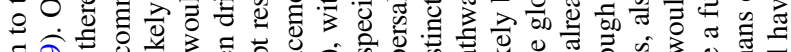

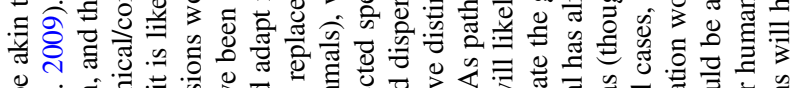

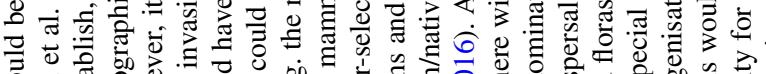

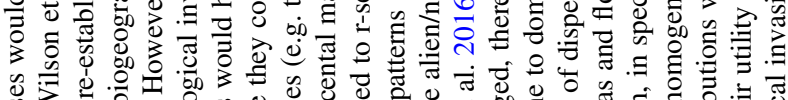

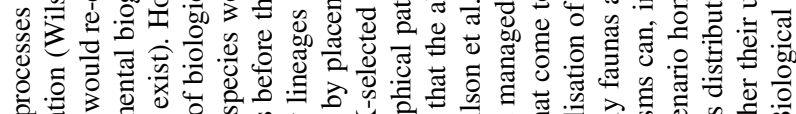

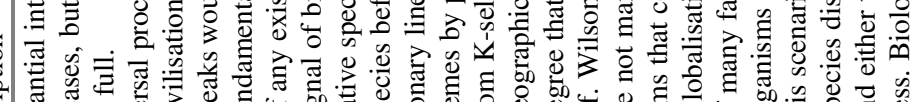

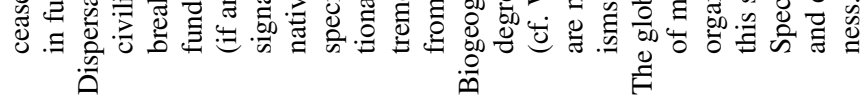

ช)

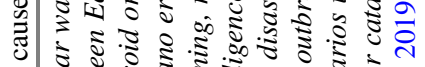

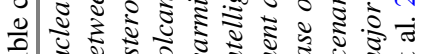

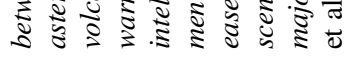

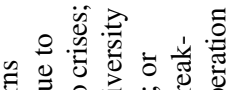

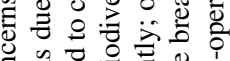

ठั

0 .

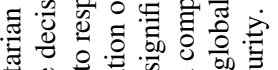

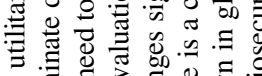

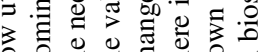

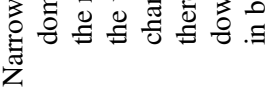

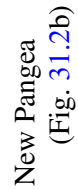




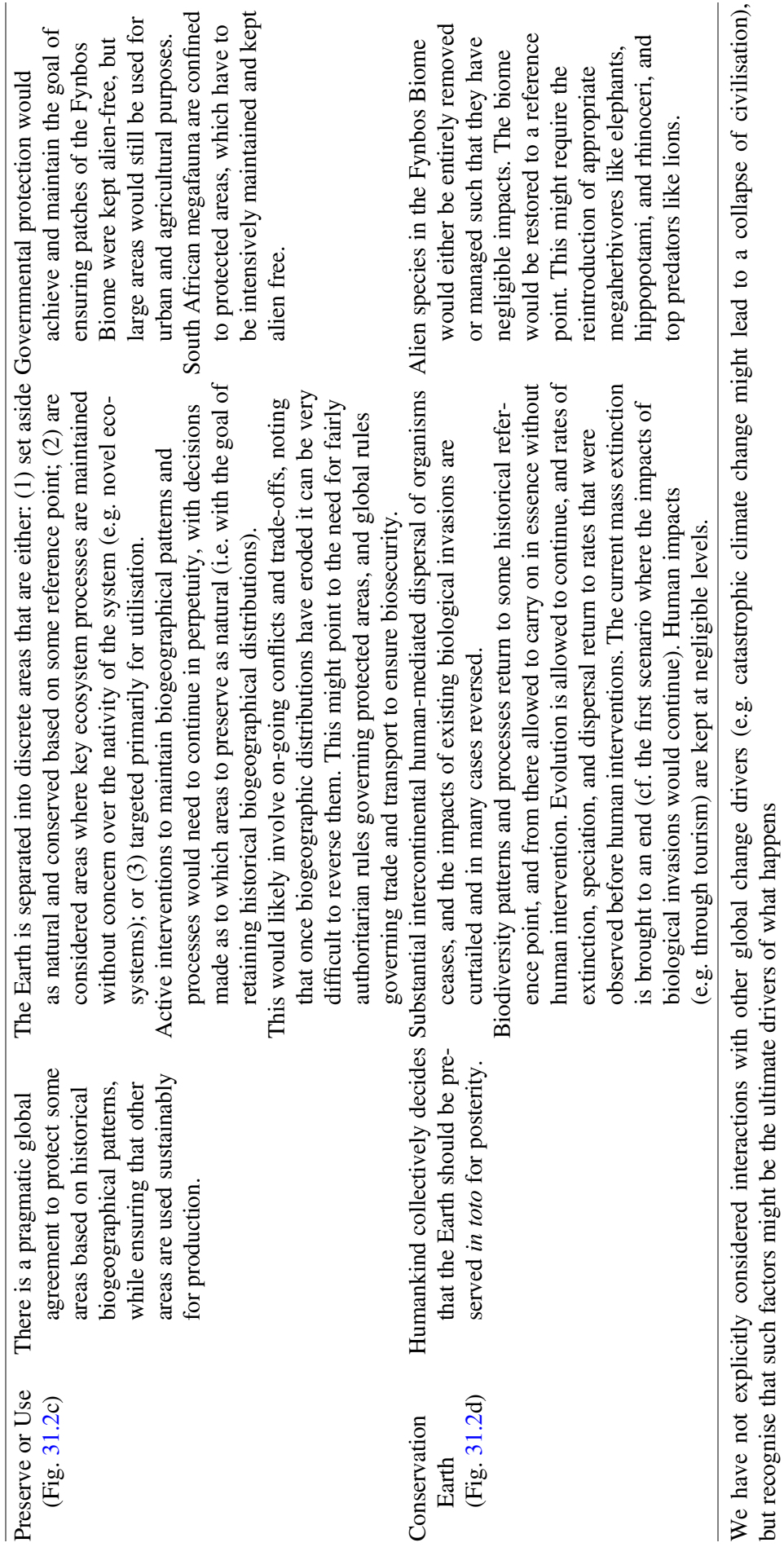


where there is no longer an advanced civilisation that is capable of the intercontinental dispersal of species in a manner akin to either mass dispersal or cultivation (Wilson et al. 2009). The consequences of existing biological invasions would play out in full (Rouget et al. 2016), but there would be no new human-mediated introductions (or the few that occur would be akin to natural dispersal).

Second, global trade and transport continue to accelerate, and the rate of introduction of species and the subsequent invasions are not (possibly cannot) be controlled. Biogeographical barriers become fully eroded such that there is essentially global dispersal - the Earth could then be considered as a single continent from a biogeographic perspective. The concept of a "New Pangea" has a long pedigree, with some of the potential consequences codified by Rosenzweig (2001). In this scenario, local variation disappears and biotic homogenisation associated with globalisation becomes complete. This scenario has been termed a World of Weeds (Quammen 1998), although it is important to note that the New Pangea would also consist of globalised crops, livestock, and pets (McKinney 2005). Indeed, the beginnings of this can be seen with the globalisation of agriculture. For example, a McDonald's hamburger with a coffee contains at least 19 plant species from all of the eight global centres of cultivated plant diversity identified by Vavilov (1926). All of these species are cultivated all around the world (Proches et al. 2008b). However, the lack of effort to retain or protect non-utilitarian species and natural biogeographic distributions would lead to steep declines in biodiversity at a global scale.

Third, we consider a scenario that is somewhat similar to the Earth we know today-"Preserve or Use". The Earth is divided into broad use types: areas that are transformed; areas used for sustainable agriculture, forestry production, or harvesting (e.g. fishing); and natural areas that are protected. Current levels of protection vary-around $14.7 \%$ of land area and $4.1 \%$ of the oceans are formally protected (UNEP-WCMC and IUCN 2016). This does not mean that such areas are devoid of alien species (Foxcroft et al. 2013) or that the eradication of alien species from such areas is possible or in some cases desirable - a third of all formally protected land is still subjected to intense human pressures (Jones et al. 2018). There are also significant moves to ensure that biodiversity is appreciated and considered everywhere. For example, in urban ecosystems the native/alien dichotomy is but one of many factors considered when formulating management strategies for "the whole landscape" (Hobbs et al. 2014; Potgieter et al. 2020, Chap. 11). Nonetheless, the distinction between alien and native is important and should be made explicit if biodiversity is to be conserved (Pauchard et al. 2018). This scenario requires a societal consensus that persists over time (e.g. in a "Preserve or Use" Earth a sense of enormous well-being is gained both by conserving native wildlife and by feeding the pigeons and sparrows too). The overall area that should be set aside is the subject of on-going debate, with recent proposals suggesting it should be as high as 50\% (Buscher et al. 2017; Noss et al. 2012; Wilson 2016). 
Although Earth is currently in a "Preserve and Use" state, we do not consider this scenario to be the status quo as we do not believe the current situation is sustainable. While some progress has been made controlling biological invasions, especially in protected areas (Foxcroft et al. 2013) and on islands (Greve et al. 2020, Chap. 8; Jones et al. 2016), problems with invasions are worsening in most cases (Millenium Ecosystem Assessment 2005), and globally the number of alien species that naturalise and become invasive in new areas keeps climbing, with no indication that it will plateau soon for most taxonomic groups (Seebens et al. 2017). Based on current drivers, we believe we are drifting towards the New Pangea.

Finally, we propose a "Conservation Earth" scenario in which the whole planet is conserved as a 'cradle of life'. Human-mediated dispersal of organisms stops; invasions are eradicated; other human-mediated drivers of global change are reversed; and the Earth is actively restored to how it was before widespread human influence (including before biological invasions). For this scenario to be realised, humans would need to have developed radically advanced technologies in ecological restoration; there would need to be profound modifications to current biodiversity (from genes to ecosystems) and physico-chemical processes (e.g. the creation of soils); and the impact of humans on Earth (i.e. their footprint) would have to decline to negligible levels. However, once "Conservation Earth" was achieved, further human interventions could cease. This is perhaps the most sci-fi of our four long-term scenarios, but it is compatible with, and perhaps a likely outcome of, two of Baum et al. (2019)'s trajectories for human civilisation-the technological transformation trajectories, and the astronomical trajectories.

There is somewhat of a continuum between "New Pangea" and "Conservation Earth", with "Preserve or Use" as an intermediate and possibly unstable state. There are, however, some qualitative differences. "Preserve or Use" differs from "New Pangea" in the retention of significant historical biogeographical patterns (e.g. Australia has a unique recognisable fauna, and the fishes of the Amazon are distinct from those of the Mekong or the Nile). "Preserve or Use" differs from "Conservation Earth" in the constant need for human intervention to ensure sustainability while maintaining biosecurity. Notably, if civilisation were to collapse, we suspect that it might already have moved significantly towards a "New Pangea" scenario. Therefore, while under both "Collapse of civilisation, but no return to Eden" and "Conservation Earth" there might be few if any humans left on Earth, these scenarios would look very different in terms of biogeography.

These scenarios are also not exhaustive, and we acknowledge that they deal with the interaction of global change drivers rather crudely. For example, climate change alone might lead to a complete reorganisation of the world's biomes. These novel biomes might be distinct and separated by biogeographical barriers maintained by future civilisations, and so might be valued both for their intrinsic uniqueness and their utilitarian value. We feel, however, that the four potential futures we outline are 
useful as they provide a small set of different trajectories against which current events and decisions in biological invasions can be assessed.

\subsection{The Year 2070: What Will Biological Invasions Look Like in South Africa When Children Born Today Are the Decision Makers?}

In considering what South Africa might look like 50 years from now we considered five main themes that have emerged from recent horizon-scanning exercises in invasion science (Caffrey et al. 2014; Dehnen-Schmutz et al. 2018; Ricciardi et al. 2017): technological advances; the political socio-economic milieu; trade; the link to global change drivers; and potential evolutionary and ecological responses. We tried to envisage potential changes, and how these might influence biological invasions consistent with one of the long-term scenarios [excluding the collapse of civilisation scenario where the influence of catastrophic events on biological invasions would be irrelevant compared to the catastrophe itself] (Table 31.2). These projections are our own, but were inspired by horizon scanning; studies of the current and future trends in the Anthropocene; and deliberations during a 1-day workshop entitled "Where to with invasion science in South Africa?" organised by the Centre for Invasion Biology (C.I.B) in November 2018.

\subsection{The Year 2025: What Will Biological Invasions Looks Like After the Next Funding/Political Cycle?}

The choice of specific events over the next 5 years that are likely to happen or that are already happening (e.g. challenges to the current regulations) are our own, but as before were inspired by: the recent report on the national status of biological invasions in South Africa (van Wilgen and Wilson 2018); South Africa's draft National Strategy on Biological Invasions (van Wilgen et al. 2014); the C.I.B's strategic plan for 2025; and insights from the 2018 $\mathrm{C} \cdot \mathrm{I} \cdot \mathrm{B}$ workshop on "Where to with invasion science in South Africa?". We found it difficult, however, to link these events to the long-term trajectories. Therefore we categorised events in terms of whether they are likely to cause biological invasions to worsen (consistent with "Pangea Earth"); keep invasions roughly static ("Preserve or Use"); or reduce the impacts seen (consistent with either "Preserve or Use" or "Conservation Earth") (Table 31.3). We also selected and discuss events under themes that we feel operate over this time-scaleplanning, regulation, funding, public support, and research. 


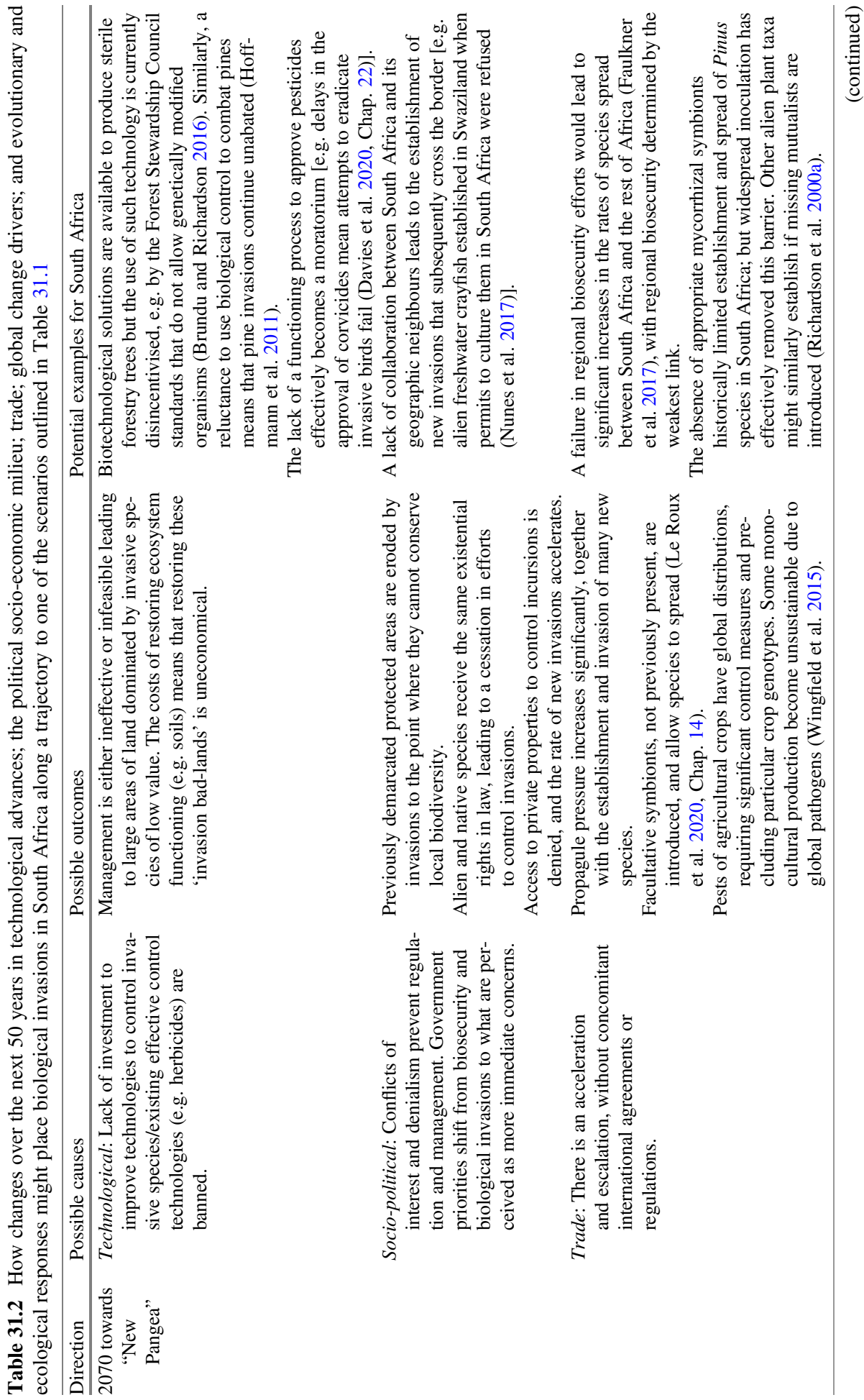




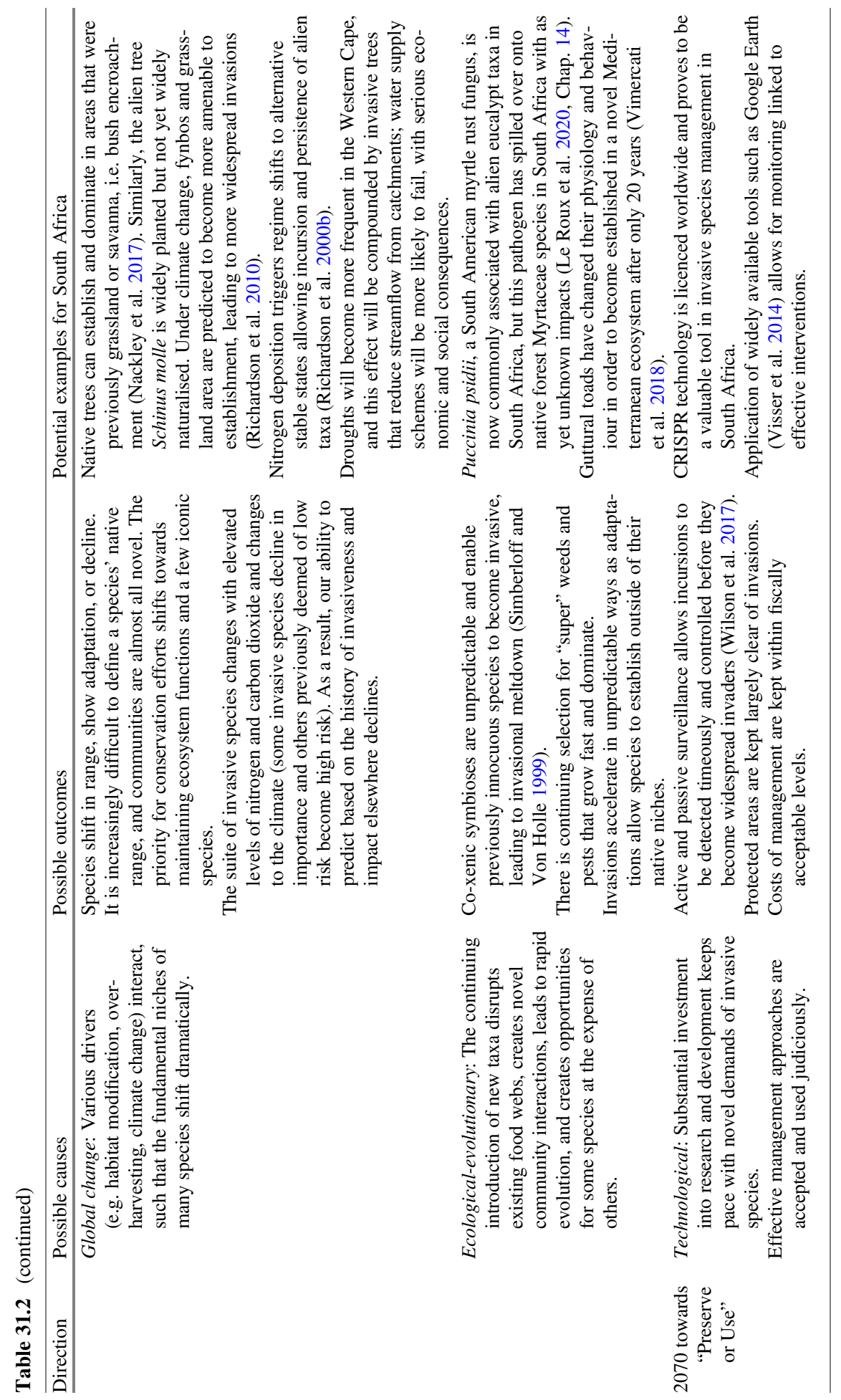




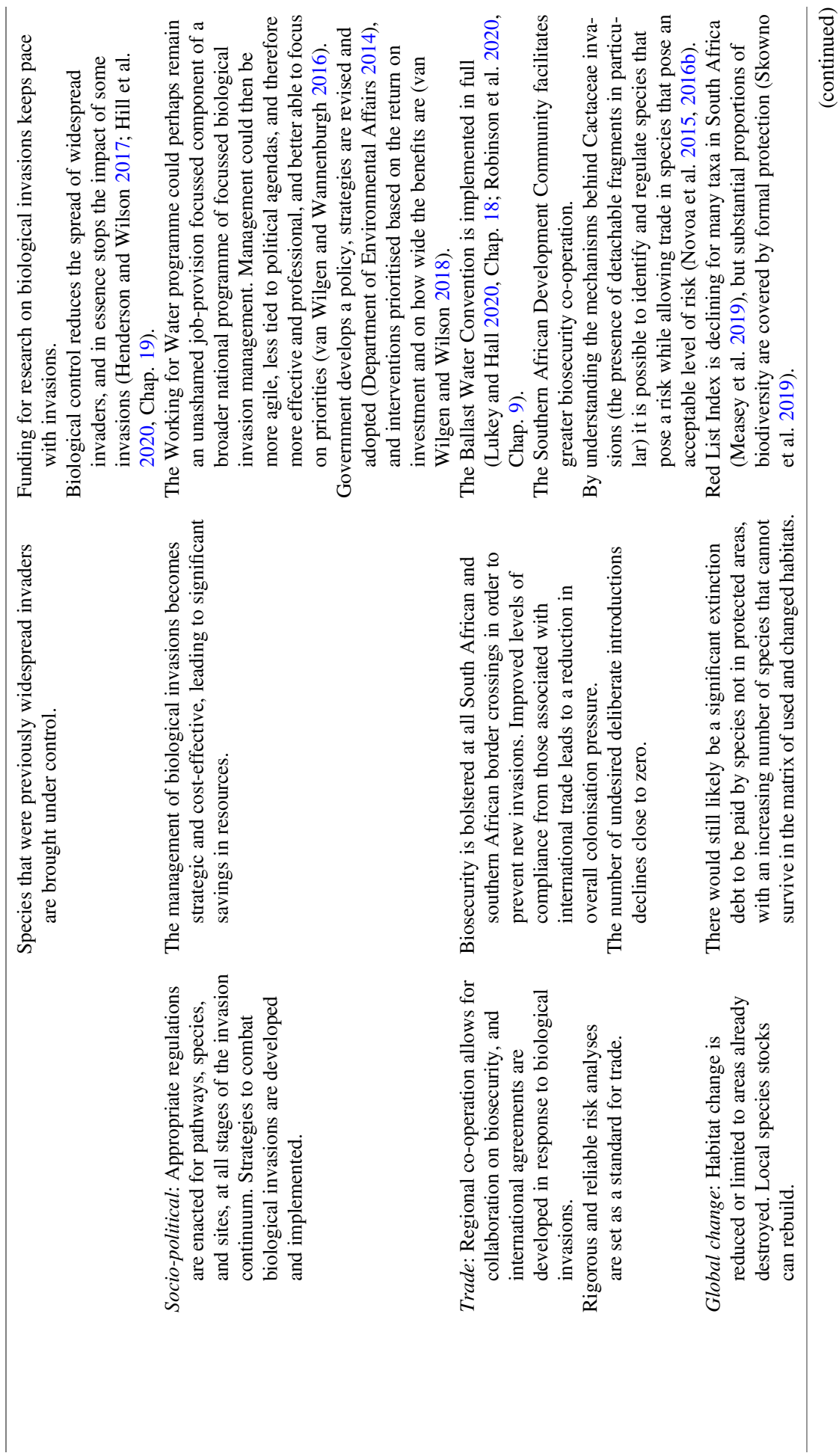




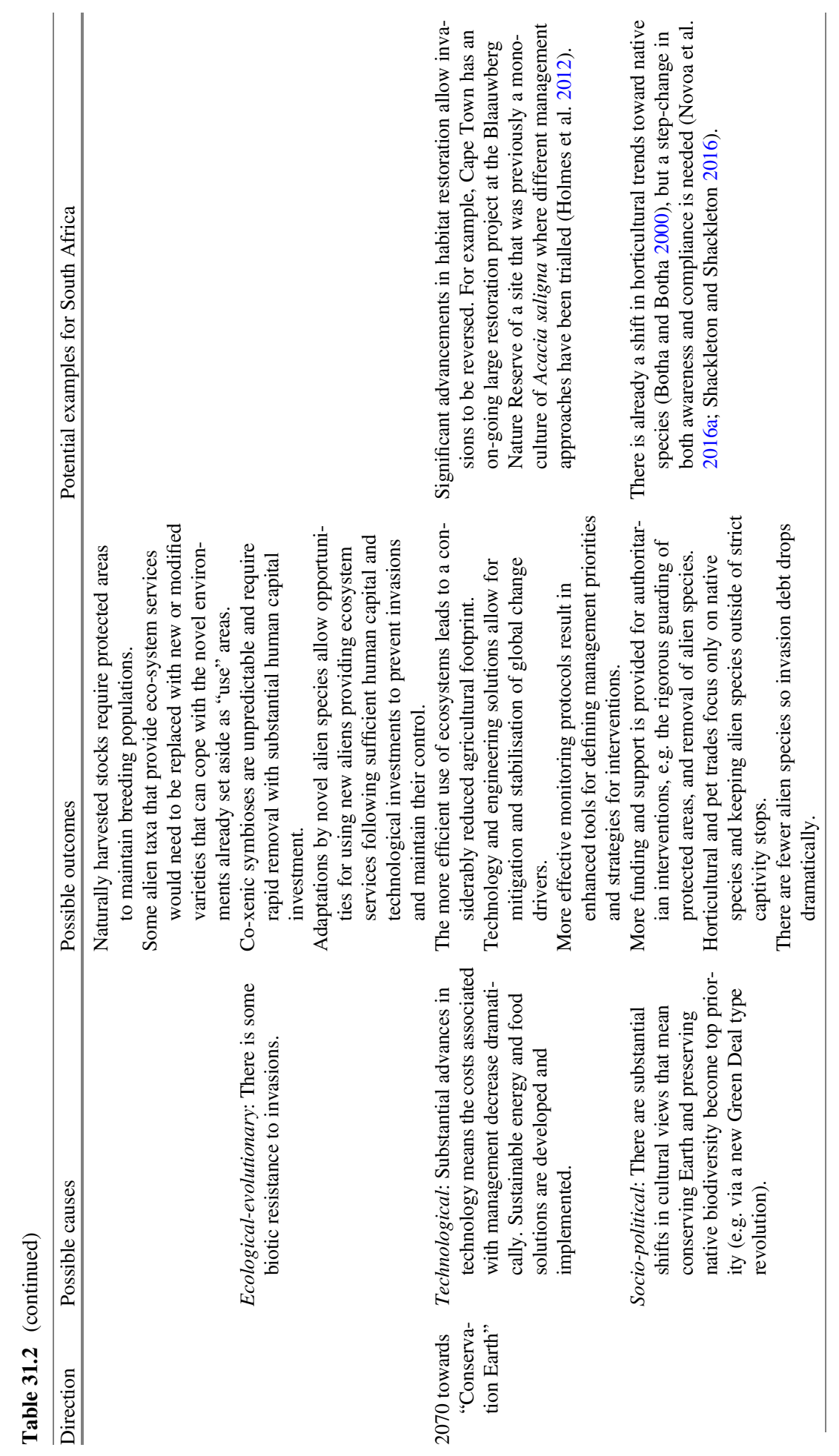




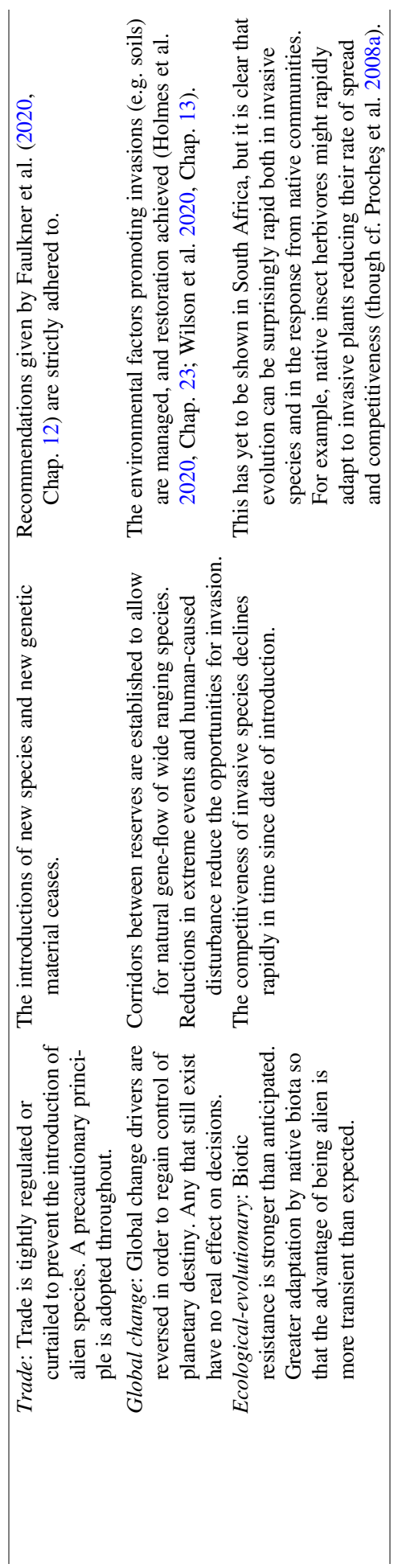




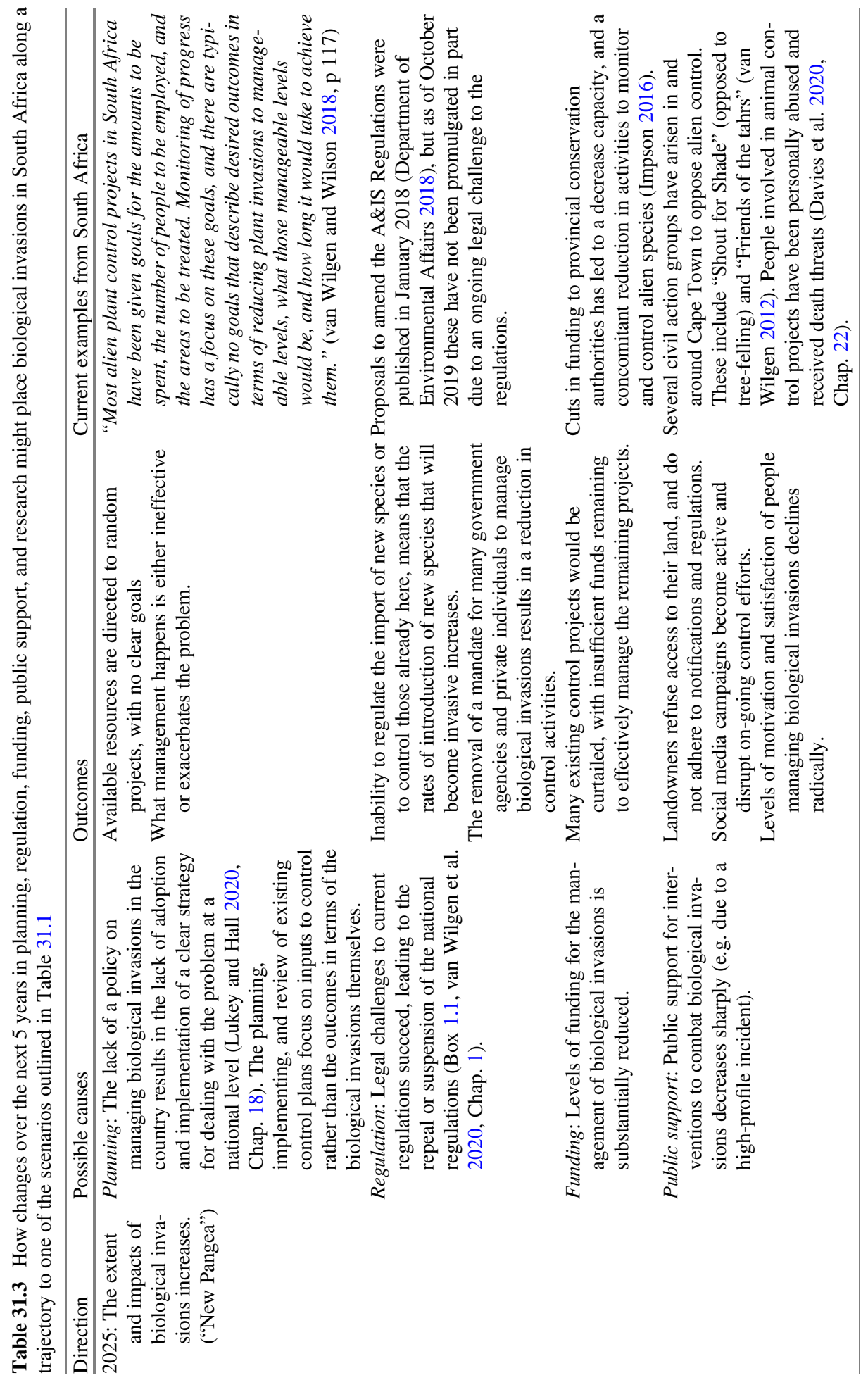




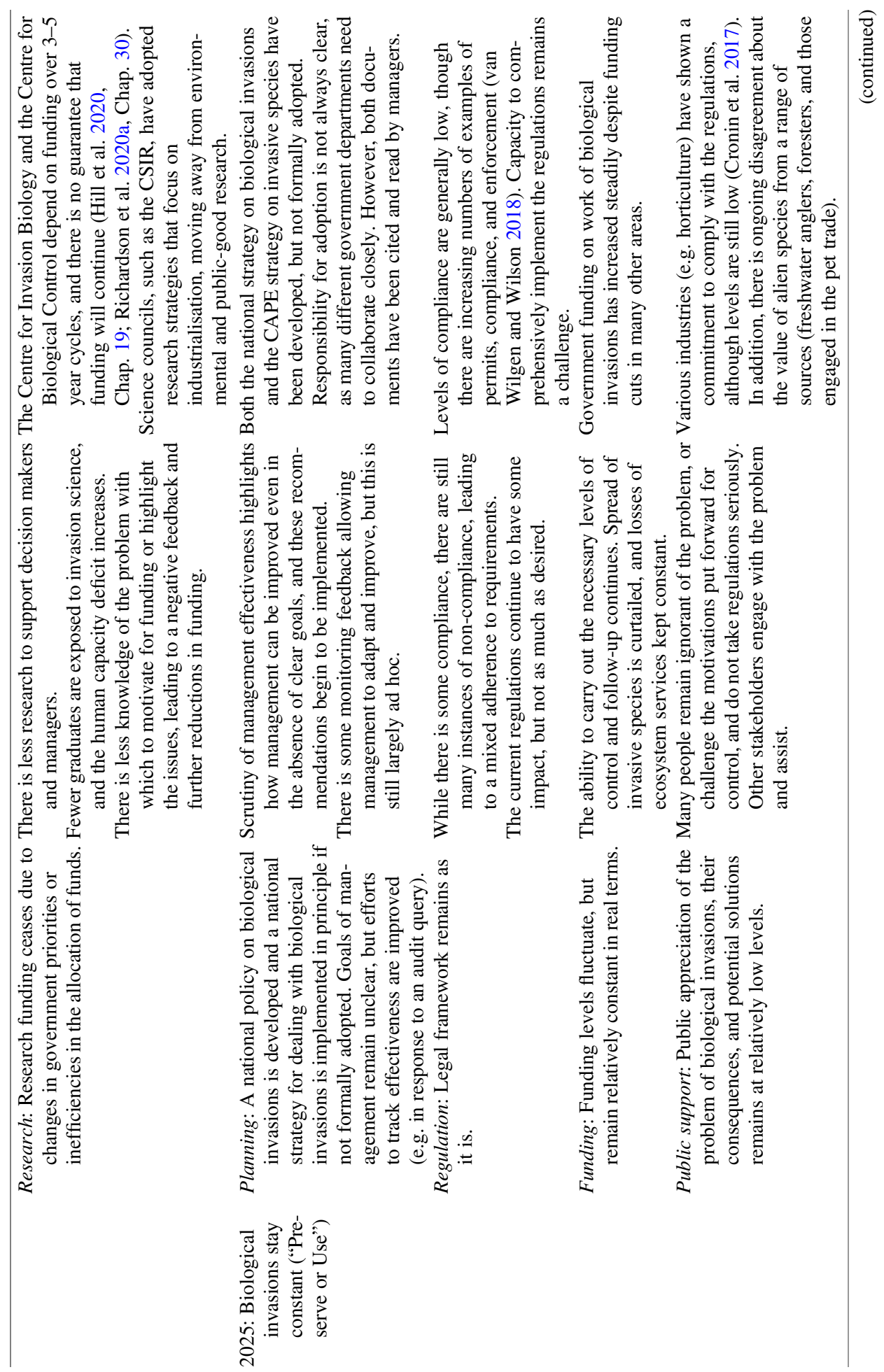




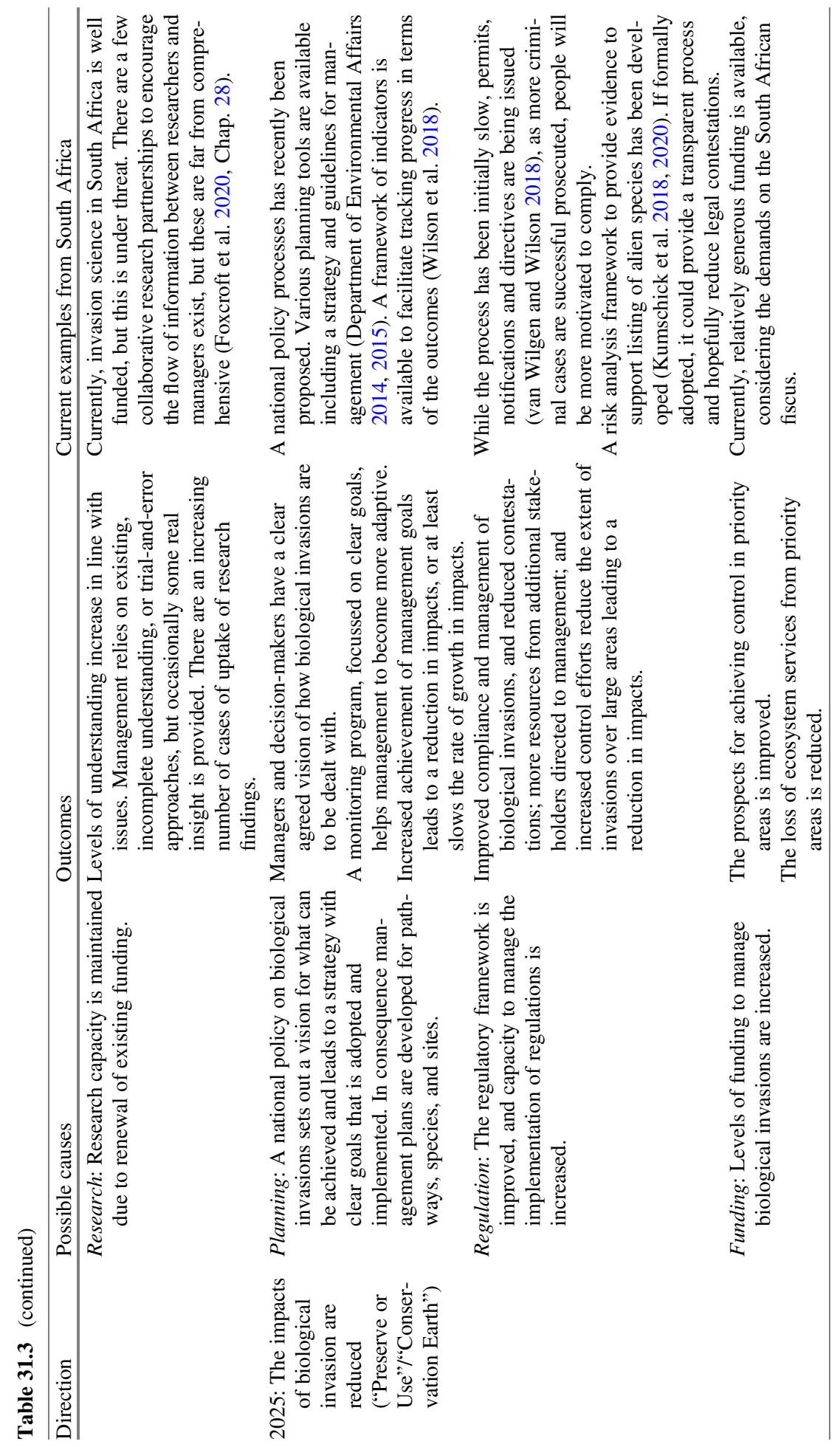




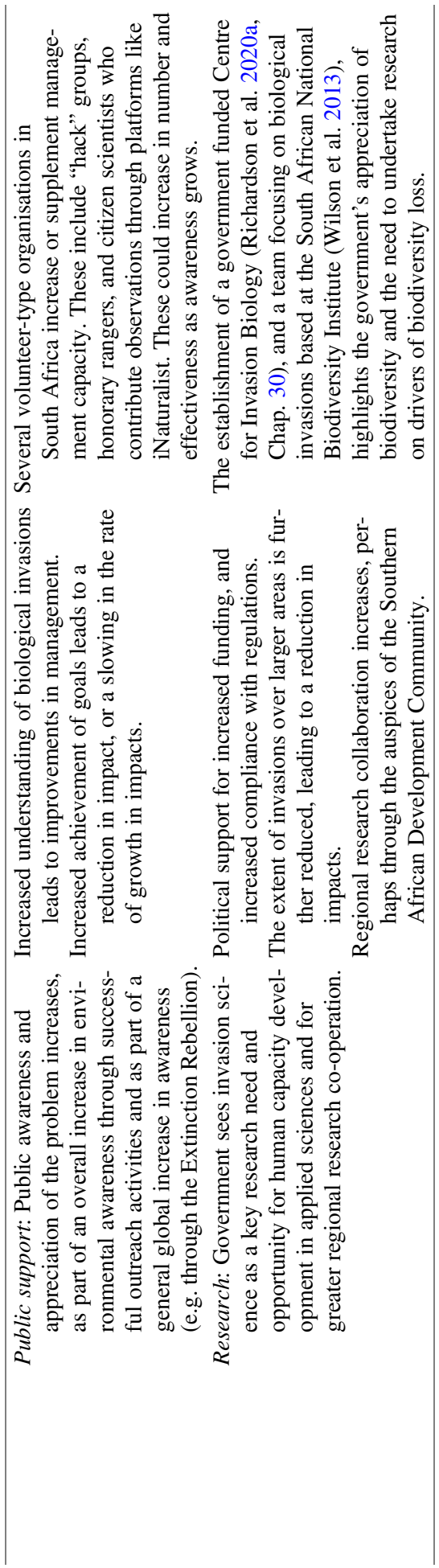




\title{
31.5 Possible Ways Forward: Examples from South Africa
}

\author{
God, grant me the serenity to accept the things I cannot change, \\ courage to change the things I can, \\ and wisdom to know the difference.
}

\author{
The Serenity Prayer (Reinhold Niebuhr)
}

In this chapter, we have outlined four long-term scenarios, and have described how events over the next 5-50 years will place us on a trajectory to one of these. Which end point is desirable is a choice for society, and some of the issues are highly contentious and incompatible [e.g. the right of your neighbour to keep a pet cat in their garden affects your right to enjoy a diversity of birds in your garden (Potgieter et al. 2020, Chap. 11)]. Such issues can, of course, also vary over space and time. Introduced species might increase local diversity over the short-term but reduce global diversity and even local diversity over longer time frames, due to the interplay between invasion and extinction debts (Rouget et al. 2016; Tilman et al. 1994). We illustrate these scenarios not to proselytise, but to highlight how the choices we make now could influence the future state of the Earth and what options (if any) are available to future generations.

Importantly, business-as-usual will ensure that current trends continue and that biological invasions will worsen due to an increasing number of alien species, growth in the extent of invasions, increasing impacts, and the continuing problems around conflict-generating species, ineffective management, and insufficient management capacity (van Wilgen and Wilson 2018). There are few studies on the impacts of alien species but available studies show that the reductions in the value of ecosystem services, productivity of rangelands, and in biodiversity intactness caused by alien species are low at present, but expected to grow rapidly (van Wilgen et al. 2008; Zengeya et al. 2020, Chap. 17). The challenge in South Africa will be to combine the current funding model (where most government funding to manage biological invasions is primarily for job creation), with one that also focuses on improving the efficiency of management and the outcomes in terms of reduced impacts and threats from invasions (van Wilgen and Wannenburgh 2016). Shifting our focus from control to prevention would also improve returns on investment, but siphoning funds from current problems might exacerbate them. Practicing conservation triage, with a focus on priority areas, could lead to patchy successes, but is likely to meet stiff resistance as people are reluctant to admit that some areas have to be abandoned to save others. Similarly, the distribution of funding has been based on political and social concerns (e.g. the desire to spread funding across the country). Shifting this to a funding system based on ecological and environmental needs would be unpopular and might see a decline in political support and ultimately funding. Increasing investment in biological control would also increase returns on investment (Hill et al. 2020, Chap. 19), but is less politically attractive as it is not labour-intensive. Important questions remain unanswered. What will be required to turn this around, and will it be politically possible? What is the future of South Africa's legislative framework in the face of legal challenges (cf. Lukey and Hall 2020, Chap. 18)? There are, however, plenty of examples where change is possible. 
Continuing investment in the management of biological invasions can be both vital for sustainable and equitable development and cost-effective, especially if economic incentives for invasive species management and overall restoration are implemented (Milton et al. 2003). Regardless of the trajectory and how we deal with the issue, we expect that in 50 years' time the most widespread invaders that cause the most impacts will be similar to those that occur now [for comparison, invasions in the Fynbos Biome are largely, though not entirely, the same as those 70 years ago with acacias, hakeas and pines dominating (van Wilgen et al. 2016)]. However, there will inevitably be some big surprises (e.g., the discovery of the Polyphagous Shot-Hole Borer, Paap et al. 2018; Box 11.3, Potgieter et al. 2020, Chap. 11).

South Africa as a society will need to make decisions as to what and how to prioritise for management. In the rest of this chapter we outline selected case-studies from this book to illustrate how decisions made over the next 5-50 years will determine the trajectory of biological invasions in the future.

\subsubsection{Coastal vs. Off-Shore Ecosystems}

Most of South Africa's rocky seashore has been transformed by the introduction of alien mussel species. This was not a deliberate choice and no technologies currently exist to alter this situation (Robinson et al. 2020, Chap. 7). The novel ecosystems created by these invasions have some benefits, and interesting impacts on biodiversity (Griffiths et al. 1992; Robinson et al. 2020, Chap. 7). Despite the current regulations, it will be difficult, but not impossible, to prevent new invasions of coastal species. There are also moves to protect large areas from habitat transformation. All this suggests that, for coastal systems, we are in a "Preserve or Use" state that is much closer to "New Pangea" than "Conservation Earth". In sharp contrast, very few off-shore marine invasions have been recorded, and there are no examples of invasive marine fish in South Africa. It might be possible to preserve this situation, and stay on a trajectory closer to "Conservation Earth", though this depends on the degree to which a sustainable blue economy can be achieved without leading to more species introductions and more impacts.

\subsubsection{The Management of Invasions in Arid Rangelands: Prosopis Species}

A large proportion of the land surface of South Africa is taken up by arid rangelands (Table 16.1, O'Connor and van Wilgen 2020, Chap. 16). These rangelands are being threatened by rapidly-expanding invasions of Mesquite (Prosopis) trees that reduce groundwater resources on which many towns and communities in the region are dependent (Le Maitre et al. 2020, Chap. 15), and reduce the capacity of rangelands to produce livestock. If Prosopis invasions continue to increase, there could be total 
economic collapse in these regions, similar to that experienced in the Karoo in the 1920s as a result of invasion by Opuntia ficus-indica (Mission Prickly Pear) (O'Connor and van Wilgen 2020, Chap. 16). There is a need to diversify land-use activities to increase income in these areas, for example by combining livestock farming with game viewing, hunting and tourism (Milton et al. 2003). If successful, some of the income could be channelled back into Prosopis control. There are also initiatives that will explore the possibility of triple bottom-line accounting, and using this to underpin a system of tax incentives to allow landowners to recoup the costs of alien plant control. This, combined with more effective biological control, could reverse the negative trend in Prosopis invasions. Currently, however, we are in a "Preserve or Use" state that is shifting rapidly towards "New Pangea", and if the similar on-going Prosopis invasions in Kenya and Ethiopia continue, many of these landscapes will become physically and functionally identical (and provide few ecosystem services).

\subsubsection{The Need for Taxonomic Services and Well-Curated Comprehensive Lists of Alien Species}

The status of knowledge of alien species varies markedly-high for mammals (Measey et al. 2020, Chap. 5), lower for plants (Richardson et al. 2020b, Chap. 3), lower still in marine systems (Robinson et al. 2016, 2020, Chap. 9), and almost non-existent for many soil and microbial groups (Janion-Scheepers et al. 2016; Wood 2017). But even for well-studied groups, there are errors and omissions in the lists of invasive species (Magona et al. 2018). South Africa lacks a comprehensive consolidated list of alien taxa (cf. van Wilgen and Wilson 2018). This is a problem as many alien species that are known invaders elsewhere in the world are present in South Africa but not yet incorporated into long-term planning and strategies. Continuing investment in taxonomy would increase our ability to identify and respond to incursions before they become widespread, and understanding the target species can be essential for management (Jacobs et al. 2017; Pyšek et al. 2013). By contrast, a dramatic reduction in research funding would see lists quickly become out of date which would undermine both risk analysis efforts (Kumschick et al. 2020, Chap. 20) and public support. Taxonomic services and alien species lists provide the foundational biodiversity information necessary for us to be able to choose between a "New Pangea" or "Conservation Earth" trajectory.

\subsubsection{Regulatory Directions}

South Africa is one of the few countries that has comprehensive regulations in place to manage biological invasions, and many parts of the regulations are innovative 
(van Wilgen and Wilson 2018). While this is certainly commendable, there are many challenges to the effective implementation of these regulations, not least of which is a lack of capacity to monitor and, if necessary, enforce them. Section 18.8.2 of Lukey and Hall (2020, Chap. 18) highlights that compliance with the regulations by $90 \%$ of society will only be achieved if the $10 \%$ that do not comply are brought to book, which is not the case at present. Compliance will also only be achieved if the regulations are broadly regarded as just and equitable; this may not be the case with the current approach of "faultless liability" whereby landowners are responsible for the control of species they did not introduce. Currently, the regulations are either ignored, or people are unaware of them (van Wilgen and Wilson 2018), and some people have mounted legal challenges to them (Lukey and Hall 2020, Chap. 18). If the regulations remain ineffective, or are removed as a result of legal challenges, we may be heading towards "New Pangea". A change in approach might be required to move in other directions, including subsidies and tax breaks, but a major step would be the development of a national policy on biological invasions to provide the basis for strategic and regulatory developments.

\subsubsection{A New Green Deal and Landscape Stewards}

The idea of linking environmental management to employment creation (i.e. labourintensive alien plant clearing programmes) was an innovative solution to the need to raise funds for invasive plant control in South Africa in the post-apartheid consensus (when funds were also desperately needed for education, health, infrastructure development, security, and welfare). However, the management of invasions is still tied primarily to welfare and job creation, and while the allocation of funds has grown, managers are still assessed on input indicators (e.g. numbers of jobs created, and money spent) rather than output or outcome indicators (e.g. reductions in the area invaded and the impacts caused) (Wilson et al. 2018). Moreover, the approach limits the implementation of more effective high-tech solutions in some cases (van Wilgen and Wilson 2018). This "green deal" has thus failed to stem the spread of invasive species at a national scale, and business-as-usual would set us on a trajectory towards "New Pangea". A combination of a new green deal and a 'landscape steward' approach could reverse these trends. More effective, goaldirected planning and implementation supported by a greater focus on training on project management and monitoring control effectiveness, and judicious use of new technologies (e.g. drones, precision control, DNA barcoding, remote sensing and monitoring, and improved taxonomic capacity), could improve management effectiveness and returns on investment. Continuous monitoring and maintenance of project outcomes as well as the development of nuanced interventions that are appropriate for the specific context would be more realistic if a more permanent connection is made between managers and the land they are managing, e.g. through a landscape steward type approach. 
This would require a societal consensus around the need to avoid the longer-term impacts associated with invasions (i.e. beyond current political and funding cycles); the need to balance all the benefits of invasions (timber, fuel, fodder, carbon, food and recreation) against their negative impacts (on water, rangeland productivity, biodiversity, fire hazard and human health); an appreciation of the threat invasions pose to economic and social prospects and ultimately sustainable development; and an increased focus on supporting bottom-up community driven connections to the land that is being managed. But the idea of linking environmental sustainability and job creation is as valid now as it was 25 years ago. A new green deal based on explicit and commonly shared goals of environmental and social sustainability would set South Africa on the path to "Preserve and Use", and ultimately to ensure that South Africa retains its unique character.

\subsection{Conclusions}

It's hard to make predictions, especially about the future.

Provenance uncertain, probably Danish (made famous by Niels Bohr)

While efforts to predict invasions are becoming more sophisticated (e.g., Essl et al. 2019; Gallien et al. 2019) and metrics exist for projecting how current indicators might change over time (Rouget et al. 2016; Wilson et al. 2018), scenarios for biological invasions will remain uncertain, particularly over longer time horizons. Most projections are implicitly or explicitly based on experience with invasions in the recent past. Conditions, including many drivers of invasions, are changing rapidly. Uncertainties are implicit in invasion science and will be best dealt with by clearly circumscribing invasion phenomena, measuring and providing clear evidence for such phenomena, and understanding their drivers and the mechanisms that generate consequences (Latombe et al. 2019). In the last section, we highlighted a few of the things that, for future generations to continue to have the choice of which scenario they want, will likely be needed: different priorities for different ecosystems (e.g. coastal vs. off-shore); the development and implementation of strategies for particular invasions (e.g. for Prosopis invasions); improvements in our foundational knowledge (e.g. through well-curated and comprehensive lists of alien species); a wide range of regulatory and other policy approaches; and novel ways to facilitate land management. However, it seems likely to us that in the next 200-2000 years we will reach a point when either the concept of biological invasions is irrelevant; invasions continue to be managed in the context of complex competing needs and interests; we have advanced to a stage where we can turn Earth as a whole into a biodiversity reserve; or civilisation collapses. We believe that the policy and management decisions we make over the coming years and decades will set us on one of these trajectories (Figs. 31.1 and 31.2). If we can develop a shared vision of how we want South Africa to look (e.g. a national policy on biological invasions), then this will provide us with a focal point for our efforts. 


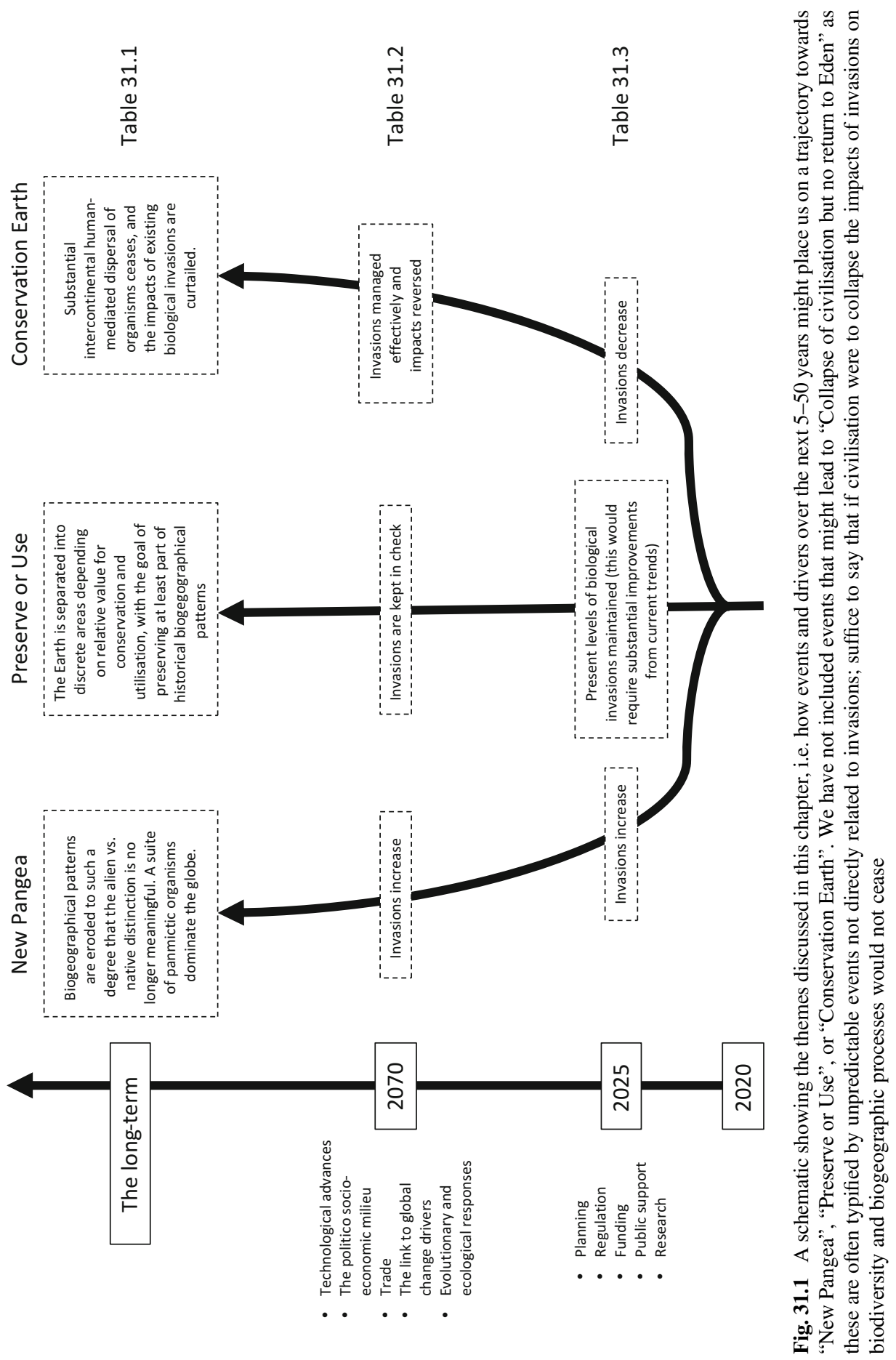


a

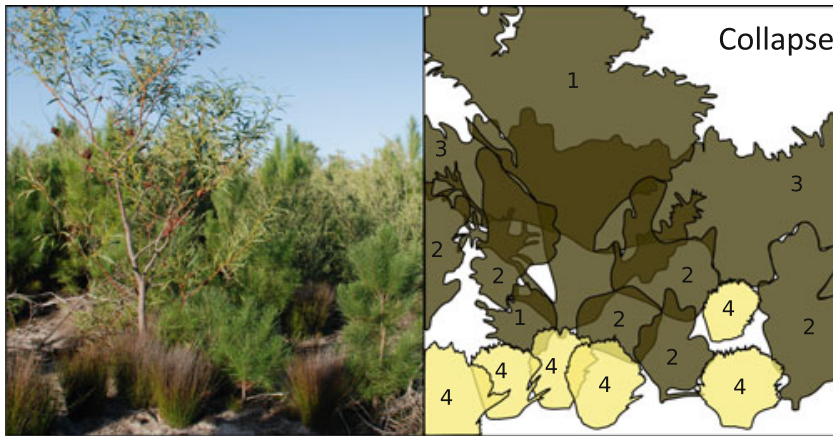

b
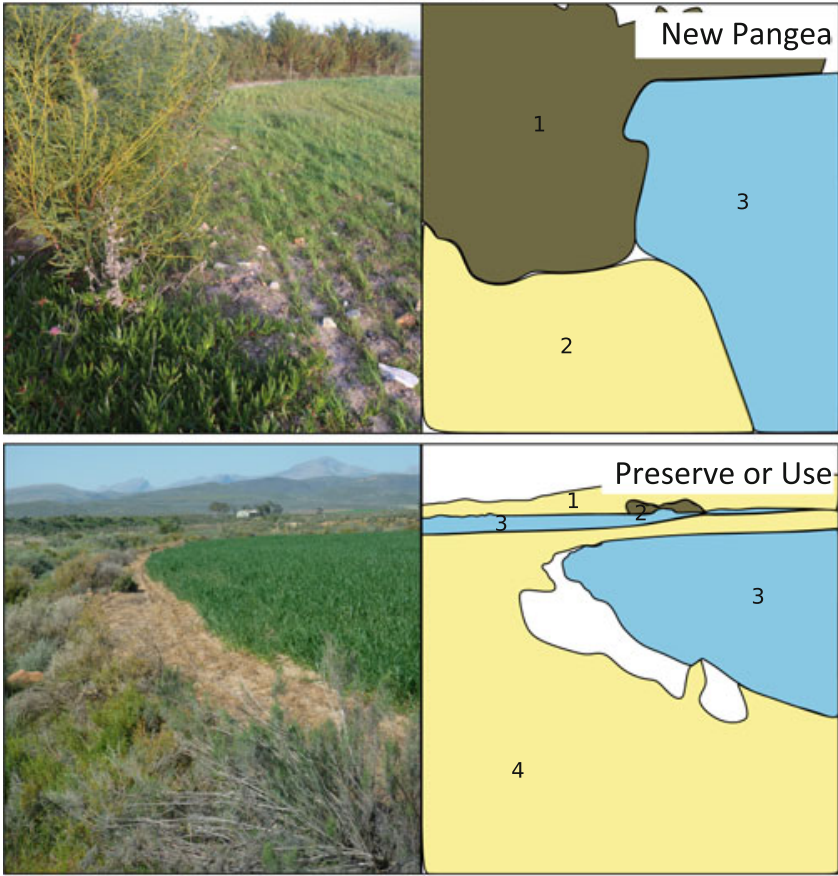

d

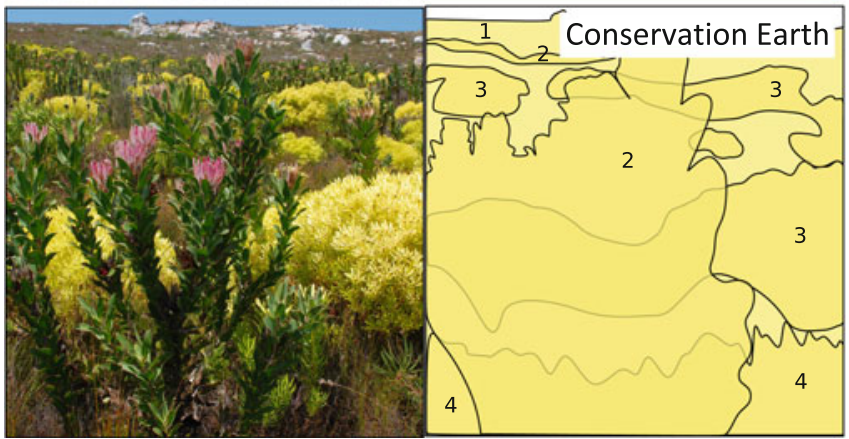

Alien

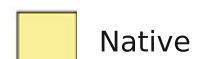

Cultivated

Fig. 31.2 Photographs illustrating potential futures of biological invasions in South Africa taken from the Western Cape in areas close to Stellenbosch. In the panels next to each photograph, the outlines of different species or vegetation types are numbered, and coloured according to whether they represent native, alien, or cultivated. (a) South Africa is transformed to a novel ecosystem 
Acknowledgements We acknowledge support from the DSI-NRF Centre of Excellence for Invasion Biology (C.I.B) and the South African Department of Environment, Forestry, and Fisheries (DEFF) for funding the South African National Biodiversity Institute noting that this publication does not necessarily represent the views or opinions of DEFF or its employees. We thank Franz Essl, Guillaume Latombe, and Peter Lukey for insightful comments on an early version; and our colleagues at the C.I.B, the SANBI, and other institutions who shared insights and ideas, especially during a workshop on "Where to with invasion science in South Africa?" in November 2018.

\section{References}

Baum SD et al (2019) Long-term trajectories of human civilization Foresight 21:53-83. https://doi. org/10.1108/fs-04-2018-0037

Botha C, Botha J (2000) Bring back nature to your garden. Wildlife and Environmental Society of South Africa, KwaZulu-Natal Region, Durban

Brand S (2008) The clock of the long now: time and responsibility. Basic Books, New York

Brundu G, Richardson DM (2016) Planted forests and invasive alien trees in Europe: a code for managing existing and future plantings to mitigate the risk of negative impacts from invasions. Neobiota 30:5-47. https://doi.org/10.3897/neobiota.30.7015

Buscher B et al (2017) Half-earth or whole earth? Radical ideas for conservation, and their implications. Oryx 51:407-410. https://doi.org/10.1017/s0030605316001228

Caffrey JM et al (2014) Tackling invasive alien species in Europe: the top 20 issues management of biological invasions. 5:1-20. https://doi.org/10.3391/mbi.2014.5.1.01

Cronin K, Kaplan H, Gaertner M, Irlich U, Hoffman MT (2017) Aliens in the nursery: assessing the attitudes of nursery managers to invasive species regulations. Biol Invasions 19:925-937. https://doi.org/10.1007/s10530-016-1363-3

Davies SJ et al (2020) Experience and lessons from alien and invasive animal control projects in South Africa. In: van Wilgen BW, Measey J, Richardson DM, Wilson JR, Zengeya TA (eds) Biological invasions in South Africa. Springer, Berlin, pp 625-660. https://doi.org/10.1007/ 978-3-030-32394-3_22

Deacon J (1986) Human settlement in South Africa and archaeological evidence for alien plants and animals. In: Macdonald IAW, Kruger FJ, Ferrar AA (eds) The ecology and management of biological invasions in southern Africa. Oxford University Press, Cape Town, pp 3-19

Fig. 31.2 (continued) composed largely of alien species ("Collapse but no return to a Garden of Eden"). (1) Acacia saligna, (2) Pinus sp., (3) Leptospermum laevigatum, and (4) a Restionaceae. The photo was taken near Betty's Bay by Brian van Wilgen. (b) The landscape is composed of a matrix of utilised areas and invaded areas that have little if any conservation value in terms of native species ("New Pangea"). (1) Acacia saligna; (2) Carpobrotus sp.; (3) a wheat field. The photo was taken on the Agulhas Plain by John Measey. (c) The landscape is composed of a matrix of utilised areas and areas that have significant conservation value in terms of native species ("Preserve or Use"). (1) A mix of vegetation types including Kouebokkeveld Shale Fynbos, North Hex Sandstone Fynbos, and Altimontane Sandstone Fynbos; (2) Eucalyptus sp. planted close to a homestead; (3) agricultural land; (4) Ceres Shale Renosterveld. The photograph was taken close to Ceres by John Wilson. (d) The unique vegetation of South Africa is conserved for future generations and natural per-human ecosystem processes are allowed to continue ("Conservation Earth"). (1) Agulhas limestone fynbos; (2) Protea compacta in flower; (3) Leucadendron sp.; (4) a Restionaceae. The photograph was taken near Betty's Bay by Brian van Wilgen 
Dehnen-Schmutz K et al (2018) Alien futures: What is on the horizon for biological invasions? Diversity Distrib 24:1149-1157. https://doi.org/10.1111/ddi.12755

Department of Environmental Affairs (2014) A national strategy for dealing with biological invasions in South Africa

Department of Environmental Affairs (2015) Monitoring, control \& eradication plans: guidelines for species listed as invasive in terms of Section 70 of National Environmental Management: Biodiversity Act, 2004 (act no. 10 of 2004) (NEM:BA) and as required by Section 76 of this Act. South African Government

Department of Environmental Affairs (2018) National Environmental Management: Biodiversity Act 2004 (Act No. 10 of 2004) Draft Amendments to the Alien and Invasive Species Lists, vol 97. Government Gazette of South Africa, Pretoria

Essl $\mathrm{F}$ et al (2019) Introducing AlienScenarios: a project to develop scenarios and models of biological invasions for the 21st century. NeoBiota 45:1-17. https://doi.org/10.3897/neobiota. 45.33366

Faulkner KT, Hurley BP, Robertson MP, Rouget M, Wilson JRU (2017) The balance of trade in alien species between South Africa and the rest of Africa Bothalia: African biodiversity and conservation 47:a2157. https://doi.org/10.4102/abc.v47i2.2157

Faulkner KT et al (2020) South Africa's pathways of introduction and dispersal and how they have changed over time. In: van Wilgen BW, Measey J, Richardson DM, Wilson JR, Zengeya TA (eds) Biological invasions in South Africa. Springer, Berlin, pp 311-352. https://doi.org/10. 1007/978-3-030-32394-3_12

Foxcroft LC, Pysek P, Richardson DM, Genovesi P (eds) (2013) Plant invasions in protected areas: patterns, problems and challenges, vol 7. Springer, Dordrecht

Foxcroft LC, van Wilgen BW, Abrahams B, Wannenburgh A, Esler KJ (2020) Knowing-doing continuum or knowing-doing gap? Information flow between researchers and managers of biological invasions in South Africa. In: van Wilgen BW, Measey J, Richardson DM, Wilson JR, Zengeya TA (eds) Biological invasions in South Africa. Springer, Berlin, pp 827-850. https://doi.org/10.1007/978-3-030-32394-3_28

Gallien L, Thornhill AH, Zurell D, Miller JT, Richardson DM (2019) Global predictors of alien plant establishment success: combining niche and trait proxies. Proc R Soc B Biol Sci 286. https://doi.org/10.1098/rspb.2018.2477

Greve M, Eric C, von der Meden O, Janion-Scheepers C (2020) Biological invasions in South Africa's offshore sub-Antarctic territories. In: van Wilgen BW, Measey J, Richardson DM, Wilson JR, Zengeya TA (eds) Biological invasions in South Africa. Springer, Berlin, pp 205-226. https://doi.org/10.1007/978-3-030-32394-3_8

Griffiths CL, Hockey PAR, van Erkom Schurink C, Le Roux PJ (1992) Marine invasive aliens on South African shores: implications for community structure and trophic functioning S Afr J Mar Sci 12:713-722

Henderson L, Wilson JRU (2017) Changes in the composition and distribution of alien plants in South Africa: an update from the Southern African Plant Invaders Atlas (SAPIA). Bothalia: Afr Biodivers Conserv 47:a2142. https://doi.org/10.4102/abc.v47i2.2172

Hill MP et al (2020) More than a century of biological control against invasive alien plants in South Africa: a synoptic view of what has been accomplished. In: van Wilgen BW, Measey J, Richardson DM, Wilson JR, Zengeya TA (eds) Biological invasions in South Africa. Springer, Berlin, pp 549-568. https://doi.org/10.1007/978-3-030-32394-3_19

Hobbs RJ et al (2014) Managing the whole landscape: historical, hybrid, and novel ecosystems. Front Ecol Evol 12:557-564. https://doi.org/10.1890/130300

Hoffmann JH, Moran VC, van Wilgen BW (2011) Prospects for the biological control of invasive Pinus species (Pinaceae) in South Africa. Afr Entomol 19:393-401

Holmes PM, Rebelo AG, Dorse C, Wood J (2012) Can Cape Town's unique biodiversity be saved? Balancing conservation imperatives and development needs. Ecol Soc 17:12. https://doi.org/10. 5751/es-04552-170228

Holmes PM et al (2020) Biological invasions and ecological restoration in South Africa. In: van Wilgen BW, Measey J, Richardson DM, Wilson JR, Zengeya TA (eds) Biological invasions in South Africa. Springer, Berlin, pp 661-696. https://doi.org/10.1007/978-3-030-32394-3_23 
Impson ND (2016) Have our provincial aquatic scientists become critically endangered? Water Wheel 15:20-23

Jacobs LEO, Richardson DM, Lepschi BP, JRU W (2017) Quantifying errors and omissions in the listing of alien species: Melaleuca in South Africa as a case-study. Neobiota 32:89-105. https:// doi.org/10.3897/neobiota.32.9842

Janion-Scheepers C et al (2016) Soil biota in a megadiverse country: current knowledge and future research directions in South Africa. Pedobiologia 59:129-174. https://doi.org/10.1016/j.pedobi. 2016.03.004

Jones HP et al (2016) Invasive mammal eradication on islands results in substantial conservation gains. Proc Natl Acad Sci 113:4033-4038. https://doi.org/10.1073/pnas.1521179113

Jones KR et al (2018) One-third of global protected land is under intense human pressure. Science 360:788+. https://doi.org/10.1126/science.aap9565

Kumschick S, Wilson JR, Foxcroft LC (2018) Framework and guidelines for conducting risk analyses for alien species. Preprints. https://doi.org/10.20944/preprints201811.200551.v201811

Kumschick S, Foxcroft LC, Wilson JR (2020) Analysing the risks posed by biological invasions to South Africa. In: van Wilgen BW, Measey J, Richardson DM, Wilson JR, Zengeya TA (eds) Biological invasions in South Africa. Springer, Berlin, pp 569-592. https://doi.org/10.1007/ 978-3-030-32394-3_20

Latombe $\mathrm{G}$ et al (2019) A four-component classification of uncertainties in biological invasions: implications for management. Ecosphere 10:e02669. https://doi.org/10.1002/ecs2.2669

Le Maitre DC et al (2020) Impacts of plant invasions on terrestrial water flows in South Africa. In: van Wilgen BW, Measey J, Richardson DM, Wilson JR, Zengeya TA (eds) Biological invasions in South Africa. Springer, Berlin, pp 429-456. https://doi.org/10.1007/978-3-030-32394-3_15

Le Roux JJ et al (2020) Biotic interactions as mediators of biological invasions: insights from South Africa. In: van Wilgen BW, Measey J, Richardson DM, Wilson JR, Zengeya TA (eds) Biological invasions in South Africa. Springer, Berlin, pp 385-428. https://doi.org/10.1007/ 978-3-030-32394-3_14

Lukey P, Hall J (2020) Biological invasion policy and legislation development and implementation in South Africa. In: van Wilgen BW, Measey J, Richardson DM, Wilson JR, Zengeya TA (eds) Biological invasions in South Africa. Springer, Berlin, pp 513-548. https://doi.org/10.1007/ 978-3-030-32394-3_18

Magona N, Richardson DM, Le Roux JJ, Kritzinger-Klopper S, JRU W (2018) Even well-studied groups of alien species might be poorly inventoried: Australian Acacia species in South Africa as a case study. NeoBiota 39:1-29. https://doi.org/10.3897/neobiota.39.23135

McKinney ML (2005) New Pangea: homogenizing the future biosphere. Proc Calif Acad Sci 56:119-129

Measey J, Hui C, Somers M (2020) Terrestrial vertebrate invasions in South Africa. In: van Wilgen BW, Measey J, Richardson DM, Wilson JR, Zengeya TA (eds) Biological invasions in South Africa. Springer, Berlin, pp 113-150. https://doi.org/10.1007/978-3-030-32394-3_5

Measey J et al (2019) Has strategic planning made a difference to amphibian conservation research in South Africa? Bothalia 49:a2428. https://doi.org/10.4102/abc.v49i1.2428

Millenium Ecosystem Assessment (2005) Ecosystems and human well-being: synthesis. Island Press, Washington, DC

Milton SJ, Dean WRJ, Richardson DM (2003) Economic incentives for restoring natural capital in southern African rangelands. Front Ecol Evol 1:247-254. https://doi.org/10.1890/1540-9295 (2003)001[0247:eifrnc]2.0.co;2

Nackley LL, West AG, Skowno AL, Bond WJ (2017) The nebulous ecology of native invasions. Trends Ecol Evolut 32:814-824. https://doi.org/10.1016/j.tree.2017.08.003

Noss R et al (2012) Bolder thinking for conservation. Conserv Biol 26:1-4

Novoa A, Kaplan H, Kumschick S, Wilson JRU, Richardson DM (2015) Soft touch or heavy hand? Legislative approaches for preventing invasions: insights from Cactaceae in South Africa. Invas Plant Sci Manage 8:307-316. https://doi.org/10.1614/IPSM-D-14-00073.1 
Novoa A, Kaplan H, Wilson JRU, Richardson DM (2016a) Resolving a prickly situation: involving stakeholders in invasive cactus management in South Africa. Environ Manag 57:998-1008. https://doi.org/10.1007/s00267-015-0645-3

Novoa A, Kumschick S, Richardson DM, Rouget M, Wilson JRU (2016b) Native range size and growth form in Cactaceae predict invasiveness and impact. Neobiota 30:75-90. https://doi.org/ 10.3897/neobiota.30.7253

Nunes AL, Zengeya TA, Measey GJ, Weyl OLF (2017) Freshwater crayfish invasions in South Africa: past, present and potential future. Afr J Aquat Sci 42:309-323. https://doi.org/ $10.2989 / 16085914.2017 .1405788$

O'Connor T, van Wilgen BW (2020) The impact of invasive alien plants on rangelands in South Africa. In: van Wilgen BW, Measey J, Richardson DM, Wilson JR, Zengeya TA (eds) Biological invasions in South Africa. Springer, Berlin, pp 457-486. https://doi.org/10.1007/ 978-3-030-32394-3_16

Paap T, de Beer ZW, Migliorini D, Nel WJ, Wingfield MJ (2018) The polyphagous shot hole borer (PSHB) and its fungal symbiont Fusarium euwallaceae: a new invasion in South Africa. Australas Plant Pathol 47:231-237. https://doi.org/10.1007/s13313-018-0545-0

Pauchard A et al (2018) Biodiversity assessments: origin matters. PLoS Biol e2006686:16. https:// doi.org/10.1371/journal.pbio.2006686

Potgieter LJ et al (2020) Biological invasions in South Africa's urban ecosystems: patterns, processes, impacts and management. In: van Wilgen BW, Measey J, Richardson DM, Wilson JR, Zengeya TA (eds) Biological invasions in South Africa. Springer, Berlin, pp 273-310. https://doi.org/10.1007/978-3-030-32394-3_11

Procheş Ş, Wilson JRU, Richardson DM, Chown SL (2008a) Herbivores, but not other insects, are scarce on alien plants. Austral Ecol 33:691-700

Procheş Ş, Wilson JRU, Vamosi JC, Richardson DM (2008b) Plant diversity in the human diet: weak phylogenetic signal indicates breadth. Bioscience 58:151-159

Pyšek P et al (2013) Hitting the right target: taxonomic challenges for, and of, plant invasions. AoB Plants 5:plt042. https://doi.org/10.1093/aobpla/plt1042

Quammen D (1998) Planet of weeds-tallying the losses of Earth's animals and plants. Harper's Magazine, October, pp 57-70

Ricciardi A et al (2017) Invasion science: a horizon scan of emerging challenges and opportunities. Trends Ecol Evolut 32:464-474. https://doi.org/10.1016/j.tree.2017.03.007

Richardson DM, Allsopp N, D’Antonio CM, Milton SJ, Rejmánek M (2000a) Plant invasions- the role of mutualisms. Biol Rev 75:65-93

Richardson DM et al (2000b) Invasive alien species and global change: a South African perspective. In: Mooney HA, Hobbs RJ (eds) Invasive species in a changing world. Island Press, Washington, DC, pp 303-349

Richardson DM et al (2010) Accommodating scenarios of climate change and management in modelling the distribution of the invasive tree Schinus molle in South Africa Ecography 33:1049-1061. https://doi.org/10.1111/j.1600-0587.2010.06350.x

Richardson DM, Abrahams B, Boshoff N, Davies SJ, Measey J, van Wilgen BW (2020a) South Africa's Centre for Invasion Biology: an experiment in invasion science for society. In: van Wilgen BW, Measey J, Richardson DM, Wilson JR, Zengeya TA (eds) Biological invasions in South Africa. Springer, Berlin, pp 875-912. https://doi.org/10.1007/978-3-030-32394-3_30

Richardson DM et al (2020b) The biogeography of South African terrestrial plant invasions. In: van Wilgen BW, Measey J, Richardson DM, Wilson JR, Zengeya TA (eds) Biological invasions in South Africa. Springer, Berlin, pp 65-94. https://doi.org/10.1007/978-3-030-32394-3_3

Robinson TB et al (2016) Lost in translation? Standardising the terminology used in marine invasion biology and updating South African alien species lists. Afr J Mar Sci. https://doi.org/ 10.2989/1814232X.1812016.1163292

Robinson TB, Peters K, Brooker B (2020) Coastal invasions: The South African context. In: van Wilgen BW, Measey J, Richardson DM, Wilson JR, Zengeya TA (eds) Biological invasions in South Africa. Springer, Berlin, pp 227-246. https://doi.org/10.1007/978-3-030-32394-3_9 
Rosenzweig ML (2001) The four questions: what does the introduction of exotic species do to diversity? Evol Ecol Res 3:361-367

Rouget $M$ et al (2016) Invasion debt-quantifying future biological invasions. Divers Distrib 22:445-456. https://doi.org/10.1111/ddi.12408

Seebens $\mathrm{H}$ et al (2017) No saturation in the accumulation of alien species worldwide. Nat Commun 8. https://doi.org/10.1038/ncomms14435

Shackleton CM, Shackleton RT (2016) Knowledge, perceptions and willingness to control designated invasive tree species in urban household gardens in South Africa. Biol Invasions 18:1599-1609. https://doi.org/10.1007/s10530-016-1104-7

Simberloff D, Von Holle B (1999) Positive interaction of nonindigenous species: invasional meltdown? Biol Invasions 1:21-32

Skowno A et al (2019) National Biodiversity Assessment 2018: an assessment of South Africa's ecosystems, species and genes. Synthesis Report. South African National Biodiversity Institute, an entity of the Department of Environmental Affairs, Pretoria

Sutherland WJ, Woodroof HJ (2009) The need for environmental horizon scanning. Trends Ecol Evolut 24:523-527. https://doi.org/10.1016/j.tree.2009.04.008

Tilman D, May RM, Lehman CL, Nowak MA (1994) Habitat destruction and the extinction debt. Nature 371:65-66. https://doi.org/10.1038/371065a0

UNEP-WCMC, IUCN (2016) Protected Planet Report 2016. UNEP-WCMC/IUCN, Cambridge/ Gland, Switzerland

van Wilgen BW (2012) Evidence, Perceptions, and trade-offs associated with invasive alien plant control in the Table Mountain National Park, South Africa. Ecol Soc 17. https://doi.org/10. 5751/es-04590-170223

van Wilgen BW, Wannenburgh A (2016) Co-facilitating invasive species control, water conservation and poverty relief: achievements and challenges in South Africa's Working for Water programme. Curr Opin Environ Sustain 19:7-17. https://doi.org/10.1016/j.cosust.2015.08.012

van Wilgen BW, Wilson JR (eds) (2018) The status of biological invasions and their management in South Africa in 2017. South African National Biodiversity Institute, Kirstenbosch and DST-NRF Centre of Excellence for Invasion Biology, Stellenbosch

van Wilgen BW, Reyers B, Le Maitre DC, Richardson DM, Schonegevel L (2008) A biome-scale assessment of the impact of invasive alien plants on ecosystem services in South Africa. J Environ Manag 89:336-349

van Wilgen BW, Richardson DM, Wilson JR (2014) A national strategy for dealing with biological invasions in South Africa. Department of Environmental Affairs

van Wilgen BW et al (2016) Ecological research and conservation management in the Cape Floristic Region between 1945 and 2015: history, current understanding and future challenges. Trans R Soc S Afr 71:207-303. https://doi.org/10.1080/0035919X.2016.1225607

van Wilgen BW, Measey J, Richardson DM, Wilson JR, Zengeya T (2020a) Biological invasions in South Africa: an overview. Springer, Berlin, pp 3-30. https://doi.org/10.1007/978-3-03032394-3_1

van Wilgen NJ, van Wilgen BW, Midgley GF (2020b) Biological invasions as a component of South Africa's global change research effort. In: van Wilgen BW, Measey J, Richardson DM, Wilson JR, Zengeya TA (eds) Biological invasions in South Africa. Springer, Berlin, pp 851-874. https://doi.org/10.1007/978-3-030-32394-3_29

Vimercati G, Davies SJ, Measey J (2018) Rapid adaptive response to a mediterranean environment reduces phenotypic mismatch in a recent amphibian invader. J Exp Biol 221:p.jeb174797

Vavilov NI (1926) Studies on the origin of cultivated plants. Bull Appl Bot Genet Plant Breed $16: 1-248$

Visser V, Langdon B, Pauchard A, Richardson DM (2014) Unlocking the potential of Google Earth as a tool in invasion science. Biol Invasions 16:513-534. https://doi.org/10.1007/s10530-0130604-y

Wilson EO (2016) Half-Earth: our planet's fight for life. Liveright Publishing Corporation, a division of W. W. Norton, New York 
Wilson JRU, Dormontt EE, Prentis PJ, Lowe AJ, Richardson DM (2009) Something in the way you move: dispersal pathways affect invasion success. Trends Ecol Evolut 24:136-144. https://doi. org/10.1016/j.tree.2008.10.007

Wilson JRU, Ivey P, Manyama P, Nänni I (2013) A new national unit for invasive species detection, assessment and eradication planning. S Afr J Sci 109:Art. \#0111, 0113 pp. https://doi.org/10. 1590/sajs.2013/20120111

Wilson JRU et al (2016) Biological invasions and natural colonisations are different-the need for invasion science. Neobiota 31:87-98. https://doi.org/10.3897/neobiota.31.9185

Wilson JR, Panetta FD, Lindgren C (2017) Detecting and responding to alien plant incursions. Ecology, biodiversity, and conservation. Cambridge University Press, Cambridge

Wilson JRU et al (2018) Indicators for monitoring biological invasions at a national level. J Appl Ecol 55:2612-2620. https://doi.org/10.1111/1365-2664.13251

Wilson JR et al (2020) The role of environmental factors in promoting and limiting biological invasions in South Africa. In: van Wilgen BW, Measey J, Richardson DM, Wilson JR, Zengeya TA (eds) Biological invasions in South Africa. Springer, Berlin, pp 353-384. https://doi.org/10. 1007/978-3-030-32394-3_13

Wingfield MJ, Brockerhoff EG, Wingfield BD, Slippers B (2015) Planted forest health: the need for a global strategy. Science 349:832-836. https://doi.org/10.1126/science.aac6674

Wood AR (2017) Fungi and invasions in South Africa. Bothalia: Afr Biodivers Conserv 47:a2121. https://doi.org/10.4102/abc.v47i2.2124

Zengeya TA, Kumschick S, Weyl OLF, van Wilgen BW (2020) An evaluation of the impacts of alien species on biodiversity in South Africa using different assessment methods. In: van Wilgen BW, Measey J, Richardson DM, Wilson JR, Zengeya TA (eds) Biological invasions in South Africa. Springer, Berlin, pp 487-512. https://doi.org/10.1007/978-3-030-32394-3_17

Open Access This chapter is licensed under the terms of the Creative Commons Attribution 4.0 International License (http://creativecommons.org/licenses/by/4.0/), which permits use, sharing, adaptation, distribution and reproduction in any medium or format, as long as you give appropriate credit to the original author(s) and the source, provide a link to the Creative Commons licence and indicate if changes were made.

The images or other third party material in this chapter are included in the chapter's Creative Commons licence, unless indicated otherwise in a credit line to the material. If material is not included in the chapter's Creative Commons licence and your intended use is not permitted by statutory regulation or exceeds the permitted use, you will need to obtain permission directly from the copyright holder. 